\title{
Managers of Health Services in Australia 2006-2016
}

JO M MARTINS, GODFREY ISOUARD

Jo M Martin-Centre for Health Policy and Management, Avalon, New South Wales 2107

Godfrey Isouard- University of New England - School of Health, Armidale, New South Wales, Australia

Correspondence: gisouard@une.edu.au

\begin{abstract}
Purpose: Activity in health services is expanding faster than population growth and that of the production of all goods and services in Australia. This paper is concerned with the number and characteristics of its managers in relation to the number of people employed and resources used. It also assesses different trends in hospitals and other medical and health services.
\end{abstract}

Methodology/Design: Design of the analyses follows specifications set by the authors for tabulations prepared by the Australian Bureau of Statistics (ABS) from the censuses of population conducted by $A B S$ in 2006 and 2016.

Analysis: Assesses changes in the number and variations in the characteristics of managers of hospitals and medical and other health services, in relation to the number of people employed, contrasted with changes in all industries.

Findings: There are different trends in hospitals and medical and other health services, with a decline in the number of employees per manager in medical and other health services and a slight rise in hospitals. The older average age of health service managers continued to rise, similarly to that for all industries. The proportion of female managers in health services, below the average for all employees, increased somewhat during the decade. The distribution among the various fields of study remained about the same; but level of education, higher than the average for all industries continued to rise. The growth in average income of managers during the decade was somewhat lower than in all industries, due to a lower increase rate in medical and other health services. The proportion of managers of indigenous status rose substantially - almost double the proportion in all industries.

Implications: The findings are of relevance to those concerned with the management of health services and training of the growing number of managers of health services in Australia.

Keywords: health service; health management; Australia 


\section{Managers of a growing industry}

Health service managers in Australia have the task of organising a large array of people with diverse skills and responsibilities into a whole that provides effective and efficient health services to the community. They manage a complex system with evolving technologies, diverse human resources and growing at a faster pace than the Australian population, labour force and the economy. In the decade 2006-2016, the Australian population grew at an annual average of $1.6 \%$ and the labour force at about the same rate, but the number of people employed in health services increased at an average rate of $3.3 \%$ per year [1] [2]. Health services expenditure grew at an average of $4.7 \%$ per year in real terms, well above the rate of growth of Gross Domestic Product (GDP), to rise from $8.7 \%$ of GDP in 2005-06 to $10.3 \%$ in $2015-16$ [3]. These aggregate rates of growth mask varied and important systemic changes that took place during that time [4] that have placed additional demands on health service managers to deal with the process of change.

The authors have provided the first comprehensive assessment of the number and characteristics of health services managers in Australia for 2006 and 2011based on the 2006 and 2011 population censuses with a related literature review [5] [6]. The purpose of this paper is to analyse the changes that have taken place in the number and characteristics of health service managers in the decade 20062016. These findings are of relevance to those concerned with changes that are taking place in health services and training of its managers.

\section{Data specifications}

The specifications for the data sourced from the 2016 population census of Australia are the same as those that the authors used for the 2006 census. This ensures compatibility between the two data sets. A detailed description of the Australian occupation and industry classifications used by the Australian Bureau of Statistics (ABS) was given by the authors in their first paper [5]. The data were collected by ABS in the 2006 and 2016 Censuses of Population and Housing. They rely on answers to census questions but ABS carries out post-enumeration surveys to ensure the reliability of the information provided. The data used in the authors' analyses were supplied by ABS in accordance with the authors' specifications. The occupation and industry classifications mentioned were used to identify the place of work (industry) and occupation. The data cover hospital and medical and other services in both the public and private sectors. Following the Australian classification of occupations, managers are in four categories: Managers not further defined (Mnfd), Chief Executive Officers (CEO) together with General Managers (GM), Specialist Managers, and Service Managers. The scope of services covered does not include pharmacies in the private sector because of the difficulty in separating functions related to the provision of pharmaceutical drugs and those concerned with the retailing of cosmetics, toiletries and other products. Other variables were specified in accordance with ABS coding of age, sex, marital status, field and level of education, indigenous status, country of birth, hours worked and income. Other data used in the analyses are from sources as indicated and references provided. For comparison purposes the authors also requested similar data for all industries, excluding farmers and farm managers because of the nature of their work. In the compilation of the basic tabulations, ABS changed figures in some cells to prevent the identification of individuals in the censuses. This led to some minor differences in some figures but does not materially affect the 
results of the analyses carried out by the authors.

As mentioned, the basic data used by the authors were from tabulations prepared by ABS. However, it is relevant to state that most of the information in the tables and figures are the result of the analyses carried out by the authors. In other words, although the sources of the components of analyses are given in the tables, the information is the outcome of the authors' analyses.

\section{Management of the growing labour force and resources}

A feature of population growth in Australia is the importance of immigration to keep the labour force growth at a similar pace as that of the population, in spite of fertility being below replacement level and the increasing proportion of older people. Health services are labour-intensive and, as stated, the number of people employed in health services grew at a faster rate than the labour force for all industries. The number of people employed grew from about 574,000 in 2006 to 801,000 in 2016. Accordingly, its share of the labour force rose from $6.3 \%$ in 2006 census to $7.5 \%$ in 2016 . Another feature of health services is that the proportion of females employed (76\% in 2016) is substantially higher than the average proportion employed in all industries ( $48 \%$ in 2016) [2] [7]. In this context, the number of health service managers in hospitals and medical and other health services increased from 19,400 in 2006 to 29,400 in 2016. The increment in the number of managers was considerably higher in medical and other health services $(+6,200)$ than in hospitals $(+3,800)$ during that decade, from respectively 8,500 and 10,900 in 2006 to about 14,700 in both cases in 2016 [5] [7].
The labour-intensive nature of health services led to a ratio of considerably more employees per manager in health services (27.3/manager) than in all industries (8.6/manager) in 2016. The average number of employees per manager declined in health services and stayed about the same in all industries during the decade 2006-2016. However, while the number of employees per manager in hospitals increased (+0.6/manager) the number of employees per manager in medical and other health services actually declined substantially (-5.7/manager). This led to a reversal of the average ratios: in 2006 there were more employees per manager in medical and other health services (31.7/manager) against a lower ratio in hospitals (27.9/manager), hospitals in 2016 employed more people per manager (28.6/manager) than medical and other health services (26.0/manager) (Table 1 ).

Excluding private pharmacies, the average health expenditure (at 2015-16 constant prices) per health manager increased from $\$ 626,200$ in $2005-06$ to $\$ 633,900$ in $2015-16$ [1] [3] [7].

\section{Manager categories}

The diversity of skills and functions in health services and its organisation along skill specialisation are reflected in the larger proportion of specialist (who include administration as well as clinical) managers in health services (69.2\%) compared with the proportion in all industries (54.6\%) in 2016. The inverse applies to the proportion of managers in supporting services (including food and cleaning) that was considerably lower in health services (14.5\%) than in all industries (33.4\%). The proportion of Chief Executive Officers/General Managers (CEOs/GMs) and Managers not further defined (Mnfd) in health services (16.3\%) was higher than in all industries (12.0\%) (Table 2). This is only partly 
due to the higher proportion of these managers in medical and other health services (19.2\%) compared with that in hospitals (13.6\%) in 2016 [7].

In 2016, the management structure of health services was more concentrated with a lower ratio of specialist and service managers per each CEO/GM \& M(nfd). This is mostly due to the lower number of managers concerned with ancillary service activities (Fig. 1).

During the decade 2006-2016, the proportion of managers of ancillary services in health declined with about an equal proportional increment in specialist managers, while the proportion of CEO/GM \& $M(n f d)$ remained about the same. This is similar to the trend in all industries (Table 2).

\section{Age of managers}

The average age of health managers in Australia rose by about one year from 46.0 years in 2006 to 47.2 in 2016. This is in line with the trend in all industries. However, the average age of managers in all industries was bout 2.5 years younger than the average for managers in health services. Managers in hospitals were also older by about two and half years than those in medical and other health services both in 2016 and 2006 (Table 3).

The age distribution of health service managers followed a hump-shaped curve with a peak at 45-54 years of age. There was a tendency for the proportion of older managers to get larger, as the average and the median ages shows, between 2006 and 2016 (Fig. 2).

As might be expected, on average, chief executive officers and general managers were older (49.8 years in 2016) than other managers in health services. Service managers were the youngest (average 45.7 years in 2016) followed by specialist managers (average 47.0 years in 2016). A feature of the age distribution is that although service managers were younger, on average, the age distribution is more widely spread as indicated by the considerably larger coefficient of variation. Similar patterns prevailed in all industries. As noted earlier, managers in health services tended to be older in all categories than those in the same categories in all industries. The trend was also for health service managers and those in all industries to be older in 2016 than 2006, in all categories, by about one year on average (Table 4).

\section{Female and male managers}

Health services in Australia have been characterised by a predominance of females in its labour force. In this regard, it is substantially different from the labour force in general. In 2016, females constituted $76.0 \%$ of people employed in health services in contrast with the average for all industries of $47.5 \%$. The predominance of females employed was greater in hospitals $(78.0 \%)$ than in medical and other health services (73.9\%). In all industries, the proportion of females employed increased slightly from $46.1 \%$ to 47.5\% and in medical and other health services by about one percent. However, the proportion of males employed in hospitals rose from $20.9 \%$ to $22.0 \%$ during the same period. This meant that the relative difference index using all industries as the standard declined from 30.3 in 2006 to 28.6 in 2016 (Table 5). The authors have followed ABS and other definitions of sex and gender. Sex is defined as the biological characteristics of females and males. Gender refers to psychological and social characteristics that are culturally determined from belief systems as of what masculine and feminine behaviour is or ought to be. 
Following the labour force distribution, females constituted the larger proportion of health service managers in 2016 (62.1\%) compared with that in all industries of $38.0 \%$. The substantial gap in the proportion of female managers to the proportion of female employees in health services, that was greater in health services than in all industries, fell from $15.8 \%$ in 2006 to the still high proportion of $13.9 \%$ in 2016 . The gap diminished most in hospital services with the highest gap of $17.6 \%$ and 14.5\% respectively in 2006 and 2016 compared with the gap in all industries of $10.9 \%$ and $9.5 \%$ in the same years. The changes meant that the proportion of female managers continued to be lower than the proportion of female employees in health services, and especially in hospitals, in spite of the narrowing of the gap in 2006-2016 (Table 6).

The proportions of female and male managers varied considerably by category in 2016 and also in 2006. The proportion of female managers was lowest among CEO/GM (53.4\% in 2016)) and service managers (58.5\% in 2016) and highest among specialist managers (64.5\% in 2016) and managers (not further defined) (62.6\% in 2016). As mentioned earlier, there was an average rise of $1.7 \%$ in the proportion of female managers during the decade 20062016, with the highest in the specialist and CEO/GM categories $(1.9 \%$ and $1.8 \%$ respectively) and lowest among service managers (1.1\%) (Table 7).

On average, female health service managers were younger than male managers by about one year (1.2 years) in 2016. This was about the same difference as in 2006. In 2016, the difference in average age was greater among service managers (2.3 years) that had a lower average age but wider spread of ages. This was followed by a difference of one year in the CEO/GM category, a slight smaller difference among specialist ( 0.8 years) and managers not further defined (0.6). The 2006-2016 trend was for an increase of the average age of both male and female managers in all categories, but especially so in the case of those in the CEO/GM category (2.0 years) (Table 8 ).

\section{Field of study}

The field of study of $29.3 \%$ of managers in health services was management and commerce, followed closely by health (28.4\%) in 2016. The other two major fields of study were social and related fields $(10.7 \%)$ and natural and physical sciences (5.2\%). There were some compensatory differences between hospitals and medical and other health services. Hospitals had a larger proportion of managers with health as the field of study $(+6.8 \%)$ and medical and other health services a greater proportion of managers in natural and physical sciences (+4.3\%) and social and related fields $(+2.6 \%)$. As would be expected, the distribution in health services was in some cases considerably different from the average from all industries, such as in the case of health, engineering, architecture and building fields of study. There was also considerably lower proportion of managers in health services without a field of study, partly reflecting the greater proportion of managers with tertiary education (Tables 9 and 11).

The analysis of the sex distribution of the field of study of managers in health services in 2016 followed what could be considered gendered specialisation of females and males, as reflected in the average for all industries. Thus, health managers in engineering, architecture and building, information technology fields of study tended to be mostly male, while those in health, education, social and related fields of study, food, hospitality and personal care were mostly female. Nevertheless, female health service managers also constituted more than 
half in management and commerce, natural and physical sciences fields of study (Table 10).

In the period 2006-2016, there was a fall in the proportion of health service managers who had no specific field of study (without certificate/diploma/tertiary education) (-4.0\%) and those from social and related fields ($1.2 \%)$. This was compensated by increments in the proportions of those in the management and commerce field of study $(+3.1 \%)$ and information technology $(+1.1 \%)$. These were accompanied by small proportional decreases in other fields of study (Table 10 and [8]).

\section{Education level}

The level of education of health service managers at graduate and post graduate was considerably higher $(61.2 \%)$ than the average for all industries (39.6\%) in 2016. Some of the difference arose from the larger proportion of managers in health services with postgraduate education (29.4\%) compared with the average for all industries (14.2\%). In the balance, the proportion of managers in all industries at the diploma/certificate level was higher (33.2\%) than in health services (24.6\%). There were also divergences between hospitals and medical and other health services, especially at postgraduate level. Hospital managers had a considerably higher proportion at post graduate level (34.5\%) than managers in medical and other health services (24.3\%), while the proportion at diploma/certificate levels were higher in medical and other health services $(26.7 \%)$ than in hospitals $(22.5 \%)$ (Table 11).

In the decade 2006-2016, the proportion of managers in health services with graduate and post graduate qualifications rose from $55.8 \%$ in 2006 to $61.2 \%$ in 2016, while those at diploma/certificate level remained at about the same proportion $(24.1 \%$ and $24.6 \%$ respectively), but those without or not stated such qualifications dropped from $20.0 \%$ to $14.2 \%$ during that period. The educational qualification level in health services remained well above that of all industries, nevertheless the gap was reduced by a substantial increase in the average proportion of managers in all industries with graduate and post graduate education (Table 11).

The analysis of the level of education by manager category showed that hospital managers tended to have more postgraduate education (34.5\%) than those in medical and other health services (24.3\%) in 2016, with the exception of managers of ancillary services. In both health activities, the proportion of CEOs/GMs with postgraduate level of education $(44.2 \%$ in hospitals and $33.2 \%$ in medical and other health services) was higher than those in other categories. In hospitals, $\mathrm{M}(\mathrm{nfd}) \quad(36.8 \%)$ and specialist managers (37.4\%) followed, with service managers with the lowest proportion at postgraduate level (8.1\%). Similar order of proportions prevailed in medical and other health services but specialist managers in this case had a higher proportion at both postgraduate and bachelor levels of education than $\mathrm{M}(\mathrm{nfd})$ (Table 12$)$.

Female and male managers in health services had, on average, about the same level of graduate and postgraduate level of education (61.0\% and $61.6 \%$ respectively) in 2016 . Small differences were observed, with a lower proportion of female managers at diploma/certificate levels and a larger proportion with other lower and not stated qualifications. However, the analysis of the level of education of health service managers by category revealed some divergences as well as some commonalities. Specialist managers the largest group - had similar levels of education at graduate and post graduate level: 
females $66.8 \%$ and males $67.0 \%$. Their proportions at diploma/certificate levels were also about the same, and that was also the case of those with lower or not stated levels of education. In the case of managers of ancillary services, males had higher proportions at diploma/certificate levels and smaller lower difference at graduate level. In the small group of managers (not further defined), male managers with a smaller proportion at postgraduate level (26.7\%) than females (29.6\%) had a larger proportion at bachelor level $(33.9 \%)$ than females $(25.4 \%)$, with a smaller difference at diploma/certificate levels (males $26.2 \%$ and females (24.7\%). The largest difference was in the proportion of females with lower or not stated level of education $(20.3 \%)$ and that of males (13.2\%). Male CEOs/GMs had a considerable higher proportion at postgraduate level $(41.8 \%)$ than females (34.5\%), with a lower difference at bachelor level: $33.8 \%$ and $32.4 \%$ respectively. This was only partly compensated by the proportion of females at diploma/certificate levels (19.9\%) compared with males (15.6\%) (Table 13).

\section{Income of managers}

Empirical evidence points to a gradual rise in average income as people age to reach a peak about the age $40-50$ years of age. It also shows that the average income of females tends to be lower than that of males [9]. In view of the average older age of health service managers, higher levels of education, number of people employed per manager, and larger proportion in high position in health services, it could be hypothesised that the average income of health service managers would be higher than the average for all industries.

The average weekly income of health service managers was \$2,089 at the time of the 2016 census. At that rate, the annual income would be about $\$ 109,300$. In line with their higher than average level of education, hospital managers earned about $\$ 114,400$ per year that was more than $\$ 104,100$ earned by those in medical and other health services. This compared with the average annual income of $\$ 99,100$ in all industries. The order of magnitude of the differences was similar to that at the time of the 2006 Census. However, during the decade, while the average income of managers in hospitals kept pace with the proportional rise of the average of managers in all industries, those in medical and other health services lagged somewhat (Table 14).

As might be expected, CEOs/GMs earned much higher incomes than the average in health services $(+28.9 \%)$ and in all industries (+38.8\%) in 2016. The proportional difference in the income of CEOs/GMs was much higher in all industries than in medical and other services $(+32.0 \%)$ and especially in hospitals (+27.0\%). Specialist managers in health services were about average $(+1.9 \%)$, but not in all industries $(+14.2 \%)$, while service managers with lower average level of education earned considerably less than the average, by about a third both in health $(-34.1 \%)$ and all industries $(-34.2 \%)$ (Table 15).

The analysis of health managers' income by sex and age showed that on average females earned less than males at all ages in 2016. While the female pattern of earnings follows the hypothesised hump-shaped distribution by age, that of males departs from this pattern to rise in early ages and, on average, actually increased after the age of 64 years (Fig. 3).

\section{Hours worked by managers}

On average, managers in health services worked 42.6 hours during the week before the 2016 census. Managers in hospitals worked somewhat longer hours (43.2 hours) than 
those in medical and other health services (42.0 hours). These averages are lower than the average for all industries (46.0 hours) (Table 16).

CEOs/GMs worked longer hours ( +4.8 hours) than the average in health services (42.6 hours) in 2016. This was also the practice in all industries (5.3 hours more than the average of 46.0). Managers in ancillary services worked shorter hours (-3.5) than the average in health services and also on average in all industries (2.2 hours). Specialist managers in health services hours of work (42.5 hours) followed the average in health services, but those in hospitals (43.4 hours) worked longer hours than those in medical and other health services (41.4 hours) (Table 17).

On average, in 2016, male managers worked longer hours (+3.9 hours) than females in hospitals and even more so in medical and other health services ( +7.2 hours). It is apparent that the rate of dispersion is greater among female than male managers in both cases (Table 18).

A major reason for the difference in the average number of hours worked between female and male managers was the substantial disproportion of female managers working part-time defined as those working less than 35 hours per week. Accordingly, in 2016, about a quarter of female managers in health services $(26.3 \%)$ worked part-time compared with about one tenth $(11.0 \%)$ in the case of males. The proportion was higher in medical and other services (29.5\%) than in hospitals (23.3\%). Similar pattern prevailed in all industries (Table 19).

The deviation in 2016 was considerably reduced when managers working 35 hours or more was considered. The difference in the average hours worked between males and females was only 0.5 hours in hospitals and 3.4 in medical and other health services compared with 4.4 hours in all industries (Table 20).

The tendency in 2016 for male managers to work longer hours than females became even more obvious when the proportion of male and female managers working longer than 48 and less than 16 hours was examined. More than a quarter of males in health services (27.4\%) worked 49 hours or more per week while less than a fifth applied to females (18.4\%). At the other end of the distribution, $15.1 \%$ of female managers in health services worked 15 hours or less per week but only $7.3 \%$ of males. These patterns were similar to the average in all industries (Table 21).

Some changes took place in the 10-year period 2006-2016. The average hours worked by managers in medical and other health services remained about the same $(+0.1 \%)$, but those of managers in hospitals rose somewhat $(+1.3 \%)$ and those in all industries decreased slightly from their still higher level (-0.9\%) (Table 16). Further, the proportion of managers working part-time (less than 35 hours per week) in all industries was about the same in two censuses, but increased further in health services, especially in the case of female managers (Table 19).

\section{Marital status of managers}

The marital status of health service managers was different than the average for all industries in 2016. The major disparity was in the proportion of never married but also in those who were divorced/separated or widowed. About a quarter of managers in all industries $(24.0 \%)$ were in the never married status but the same groups in health services made up about a fifth (19.1\%). The proportion of divorced/separated/widowed was also larger in health services $(15.0 \%)$ than the 
average for all industries (12.1\%) (Table 22). However, marital status is to some extent a function of age. In other words, marriage follows single status, and divorced/separated/widowed follows marriage. As health service mangers were on average older than those in all industries, some of these differences could be attributed to the age distribution. However, age and sex standardisation of the marital status of health service managers using all industries as the standard indicated that in 2016, health service managers had a lower proportion of never married than would be expected given the standard for all industries and also a lower proportion of widowed, divorced/separated, and a balancing higher proportion of married. The deviation from the all industry standard was higher in medical and other health services than in hospitals.

\section{Country of birth of managers}

At the time of the 2016 census, $66.7 \%$ of the population had been born in Australia (ABS 2017a) and the proportion of managers in all industries born in Australia was 68.7\%. The proportion of health service managers born in Australia was slightly higher at $69.7 \%$. However, there was a major difference between those in hospitals (72.1\%) and medical and other health services (67.3\%). Health service managers born in New Zealand and Oceania (3.7\%) and the United Kingdom and Ireland (9.7\%) made up a substantial proportion of the distribution (Table 23).

There were changes in the period 2006-2016 some of which reflect changes in the composition of the Australian population, the relative importance of migration and country of origin of migrants. Accordingly, the proportion of health service managers born in Australia declined from $74.3 \%$ in 2006 to $69.7 \%$ in 2016. The major changes in country of origin of health service managers born Overseas was the decline in the proportion of those born in Europe, other than the United Kingdom and Ireland, from $8.4 \%$ in 2006 to $3.8 \%$ in 2016, and the rise in the proportion of those born elsewhere, mostly Asia, from $3.6 \%$ in 2006 to $14.0 \%$ in 2016. These changes were greater in medical and other health services than in hospitals during that period. There was also a small fall in the proportion born in the United Kingdom and Ireland and an increase in those born in New Zealand and Oceania (Table 23).

\section{Indigenous status}

The proportion of health service managers with Indigenous status (1.7\%) was almost double that in all industries $(0.9 \%)$ as per the 2016 census. The percentage was much higher in medical and other health services (2.2\%) than in hospitals (1.3\%). The proportion of female managers in health services $(1.9 \%)$ was larger than that of males (1.5\%). This was especially so in the case of hospitals $(1.5 \%$ versus $1.0 \%$ ) (Table 24).

The proportions in 2006 were lower than in 2016 , in both health services $(-0.5 \%)$ and all industries (-0.3\%). With the largest increment in the proportion of female managers in medical and other health services (Table 24).

\section{Managers of growth and change}

In an activity that is human resource intensive, the substantial growth in health services resulted in a rise in the number of people employed in health services by $39.5 \%$ during the decade 2006-2016. This was associated with a much greater increase of $51.5 \%$ in the number of managers that amounted to 29,400 in 2016. However, the number of managers in hospitals rose by only $34.9 \%$ but the increment in medical and other health services was $72.9 \%$. This meant that while the ratio of employees per manager in hospitals increased slightly from 27.9 in 2006 to 28.6 in 2016, the 
ratio declined considerably in medical and other health services from 31.7 in 2006 to 26.0 in 2016 .

The increase in activity in health services was accompanied with a rise in the proportion of specialist managers but a decline in the proportion of managers of ancillary services such as food and cleaning services. The latter might be attributed to the outsourcing of these services. The proportion of senior managers (CEO/GM/M(nfd)) remained about the same during the decade under review. Nevertheless, the proportion of these senior managers in medical and other health services was greater (21.1\% in 2006 and $19.2 \%$ in 2016) than in hospitals (13.2\% in 2006 and 13.5\% in 2016) [7] [10]. This might reflect differences in the scale of operation in the two settings.

Health service managers were older (47.2 and 46.0 years in 2016 and 2006 respectively) than the average for all industries (44.6 and 43.5 years in 2016 and 2006 respectively). This could be the result of the longer period of time spent in education and training by managers in health services. Senior managers (CEO/GM/M(nfd)) were older on average than specialist managers or the much younger managers of ancillary services. This was also the pattern among the average younger managers in all industries. The trend was for managers in all categories to be about one year older in 2016 than 2006. This might be attributed to managers staying-on longer at work and retiring at an older age. Female managers tended to be about one year younger than males.

Although females constituted the majority of health service managers in all categories both in $2006(60.4 \%)$ and 2016 (62.1\%), the proportion of female managers was lower than the proportion of female employees in health services. The gap was narrowed during the decade from $-15.8 \%$ to $-13.9 \%$. However, the gap in health services remained higher than the average in all industries $(-10.9 \%$ in 2006 and $-9.5 \%$ in 2016). The gap was particularly large in the CEO/GM category in both years.

As would be expected, a larger proportion of health service managers came from the health field of study than in all industries, but considerably less from engineering, architecture and building. Specialisation of the field of study by sex in health services followed that of the average for all industries with a greater proportion of female managers coming from health, social and related fields and education, and a higher proportion of males from engineering, architecture and building and information technology. This pattern prevailed both in 2006 and 2016.

Although the relative difference between the level of education of managers in health services and the average for all industries fell in the decade 2006-2016, mostly due to the rising average proportion of managers with graduate or postgraduate degrees in all industries, the level of education of health service managers continued to be substantially higher in 2016. While in 2016 the average proportion of health service managers with graduate or post graduate education was $61.2 \%$ that of the average for all industries was only $39.6 \%$. The proportion at this level in hospitals (64.4\%) was also greater than in medical and other health services (58.0\%). The percentage of hospital CEOs/GMs with graduate and post-graduate was particularly high at $75.5 \%$ compared with $67.5 \%$ in medical and other health services. Service managers, with the lowest proportion of managers with graduate or post graduate degrees $(20.6 \%$ in hospitals and $30.9 \%$ in medical and other health services), had the largest proportion at 
diploma/certificate or lower levels. On average, female and male managers of health services had about the same percentage at graduate and post graduate level: $61.0 \%$ and $61.6 \%$ respectively. The major difference was in the CEO/GM category where the proportion of male managers at that level was $75.6 \%$ and females $66.9 \%$.

In line with their higher level of education, on average, health service managers earned $10 \%$ more than those in all industries in 2016, and hospital managers about $10 \%$ more than those in medical and other health services. The health services average weekly income $(\$ 2,089)$ in 2016 represented an average annual rate of increase of $3.3 \%$ during the decade 2006-2016 that was slightly lower than the average of $3.5 \%$ for all industries. This difference was due to the lower pace of increase in medical and other health services, while managers in hospital kept at about the same rate of increase as the average for all industries. CEOs/GMs in health services earned $28.9 \%$ more than the average in 2016 . This was a lower difference than the average for all industries of $38.8 \%$, especially in the case of hospital managers $(+27.0 \%)$. Those in medical and other health services $(+32.0 \%)$ were closer but still below the average for all industries. As might be expected from their lower level of education, managers of ancillary services earned less than average $(-34.1 \%)$ in health services, as in the average for all industries ($34.2 \%)$. In general, earnings tend to follow a hump-shaped pattern with lower earning early and late in the working life. Female managers in health services tended to follow this pattern in 2016. On average, they also earn less than males at all ages. This was partly a result of the higher proportion of female managers working part-time and the lower proportion of them in the higher paid CEO/GM category in health services. The pattern for male managers was somewhat different. Male average earnings also rose with age but they kept on rising after the age of 65 years. This was due to the higher proportion of CEOs/GMs who stayed at work and became a larger proportion of all managers at older ages lifting the average earnings, as specialist and service managers with lower earnings retired earlier.

On average, at the time of the 2016 census, health service managers worked slightly longer hours (42.6 hours) per week than at the time of the 2006 census ( 41.9 hours). This was the result of the rise of hours worked by hospital managers ( +1.3 hours) as the hours worked by managers in medical and other health services remained about the same during that time. This is in contrast with the slight decline (-0.9 hours) in the higher average for all industries (46.0 hours in 2016). In all industries CEOs/GMs worked longer hours per week ( +5.3 hours) than the average for all categories. In health services, they also worked longer hours than the average per week $(+4.8$ hours) while ancillary service managers worked 3.5 hours less than the average, with specialist managers who constituted the majority working about the same as the average for all managers (42.5 hours). In all industries in 2016, the proportion of female managers who worked part-time (25.4\%) was much greater than that of males $(10.5 \%)$. This was about the pattern in health services (26.3\% and $11.0 \%$ respectively). This explained much of the difference in the average hours worked by female and male managers in health services: 40.6 and 46.0 hours respectively [7]. When full-time managers were considered, the difference was relatively small in hospitals ( 0.5 hours) but larger in medical and other services (3.4 hours). The contrast between female and male working hours became more accentuated when the proportions of managers working longer and 
shorter hours in 2016 were examined: a lower proportion of female health service managers worked 49 hours or more per week (18.4\%) than males (27.4\%), and a higher proportion worked 15 hours or less (15.1\%) than males (7.3\%).

Marital status is associated with age. As health managers were older than the average for all industries, it would be expected that their marital status to be somewhat different as found. The age and sex standardised marital status using the all industries pattern as a standard showed that health service managers in 2016 were more likely to be married than expected for their age and sex distribution, and less likely to be never married, divorced/separated or widowed.

The proportion of health service managers born in Australia at the time of the $\mathbf{2 0 1 6}$ census was somewhat larger (69.7\%) than the average for all industries $(68.7 \%)$ or for the whole population (66.7\%). The proportion of Australian-born was a decline since the 2006 census when it amounted to $74.3 \%$. In addition to the larger proportion of health service managers born Overseas, the country of origin also changed. Accordingly, the proportion of health service managers born in the United Kingdom and Ireland fell (from 10.7\% in 2006 to $9.7 \%$ in 2016) and those born in New Zealand increased (3.0\% to $3.7 \%$ ) slightly. The major changes affected the proportion of health service managers born in other Europe (than the United Kingdom and Ireland) that fell from $8.4 \%$ in 2006 to $2.9 \%$ in 2016 , while those born elsewhere (mostly in Asia) rose from 3.6\% to $14.0 \%$. These changes were similar to those experienced on the average for all industries during the period and changes in the country of origin of Australian immigrants in general.
During the decade 2006-2016, the proportion of health service managers of Indigenous status rose from $1.2 \%$ to $1.7 \%$. These percentages were about double the average for all industries in both years. Although the proportions were higher for both females and males, they were greater in the case of females (1.9\% versus males $1.5 \%$ in 2016). The proportions of Indigenous health service managers were only slightly above the all industries' average in the case of hospitals but substantially above in medical and other health services.

\section{Major features and research agenda}

This research shows growth in the number of health service managers and also change in their characteristics. A feature of the growth in numbers was the disparity between the rate of increase of managers in medical and other health services and that in hospital services, to the point where their numbers were close to each other. Another aspect is the narrowing but continuing large gap between the percentage of females in health service labour force and the proportion of female managers. This gap was particularly noticeable in the proportion of females in the CEO/GM category. The higher average income of health service managers was closely associated with their higher level of education at graduate and but especially at post graduate levels. Most of the difference between the higher average income of male managers could be attributed to greater proportion of females who work part-time and their lower hours of work. However, part of it could have risen from their lower proportion in the CEO/GM category. Still another change was the country of birth of managers in health services born Overseas that reflected shift in the flow of migrants to Australia from Europe to Asia. An important feature was the progression made in the rise of 
the proportion of health service managers who were indigenous people.

The informative and important nature of the findings has some limitations that form an agenda for further research using other sources and methods. Among those are the reasons for the gap between the proportion of females in the labour force and that of female managers. This gap is larger in health services than the average for all industries. A related issue is the relatively low proportion of females in the CEO/GM category. Another question is

\section{Reference}

1. Australian Bureau of Statistics (ABS). 2006 Census of population and housing Australia. Industry of employment. Canberra: ABS 2007.

2. Australian Bureau of Statistics (ABS). 2016 Census of population and housing Australia. Employment, income and education. Canberra. Customer table builder: ABS 2017a.

3. Australian Institute of Health and Welfare (AIHW). Health expenditure Australia 2015-16. Canberra: AlHW 2017.

4. Martins JM, Isouard G. An evidence-based framework: Competencies and skills for managers in Australian health services. APJHM 2015; 10(2): 8-23.

5. Martins JM, Isouard G. Health service managers in Australia. Part 1: service, geographical and category distribution. APJHM 201; 7(2): 16-28.

6. Martins JM, Isouard G. Health service managers in Australia: progression and evolution. APJHM 2014; 9(2): 35-52. the relevance of the content of education and training to the management of humanresource activity and of multidisciplinary silos that need to work for a common end. The human dimension of the training received by health service managers seems to be basic to personal fulfilment as well as achievement in effective and efficient health care.

7. Australian Bureau of Statistics (ABS). 2016 Census of Population and Housing. Customised Data Report. (Tabulations prepared in accordance with specifications made by the authors). Canberra: ABS 2017b.

8. Martins JM, Isouard G. Health service managers in Australia. Part 3: field of study, level of education and income. APJHM 2012c; 7(2): 43-58.

9. Martins JM, Yusuf F, Swanson D. A. Consumer demographics and behaviour. Dordrecht: Springer. 2011.

10. Australian Bureau of Statistics (ABS). 2006 Census of Population and Housing. Customised Data Report. (Tabulations prepared in accordance with specifications made by the authors). Canberra. ABS 2012.

11. Martins JM, Isouard G. Health service managers in Australia. Part 2: age and sex characteristics. APJHM 2012b; 7(2): 29-42. Fig. 2; Tables 3, 4, 5, 6, 7, 8.

12. Martins JM, Isouard G. Health service managers in Australia. Part 4: hours worked, marital status, country of birth and indigenous status. APJHM 2012d; 7(2): 5970. Tables 16, 19, 22, 23, 24. 
Fig. 1: Specialist and service managers per general manager, health services and all industries, 2016

CEO/GM/M(nfd) (1) Health services: Specialist managers $4.2+$ Service managers $0.9=5.1$
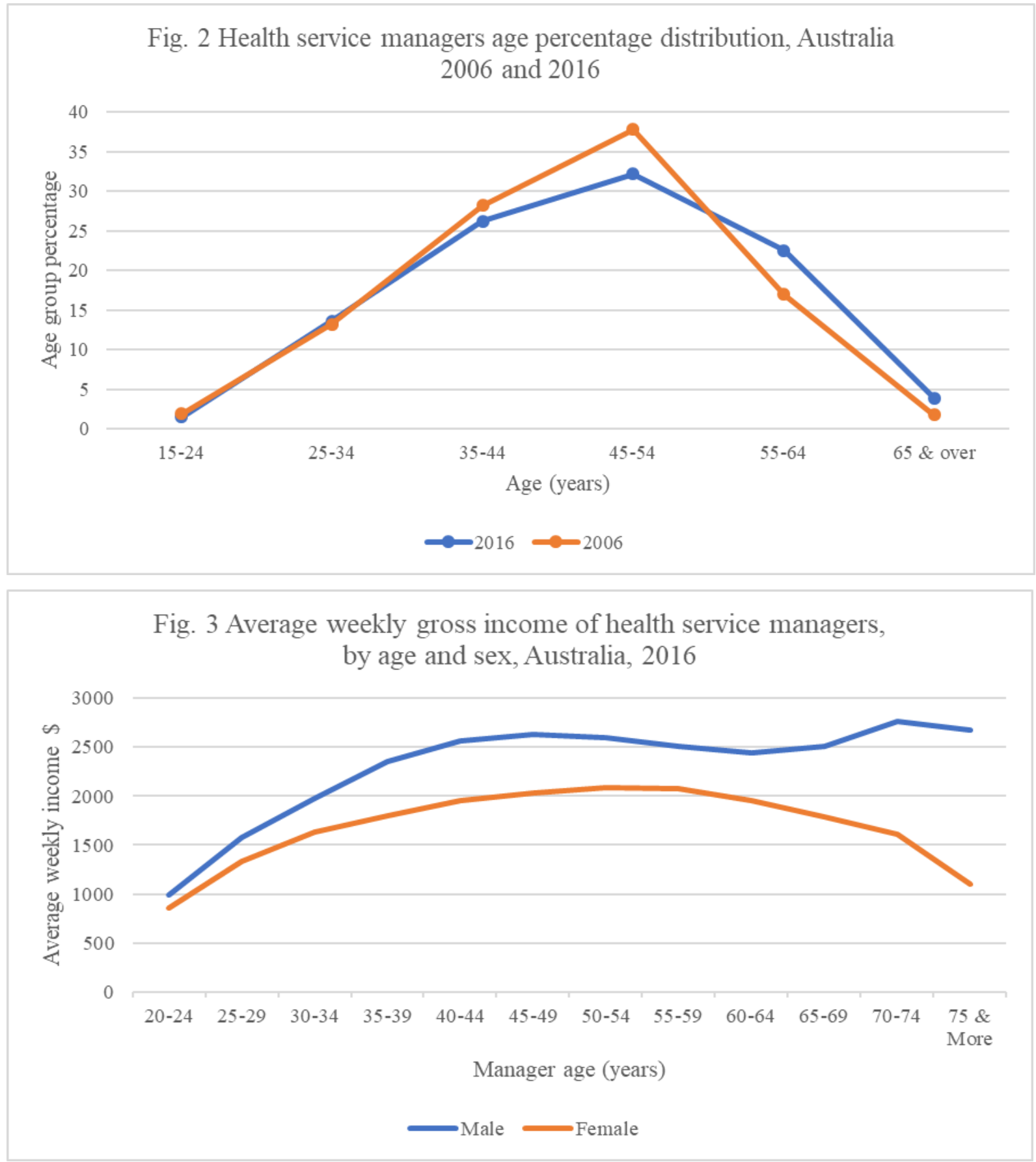
Table 1: Number of people employed per manager, health services and all industries, Australia, 2006 and 2016

\begin{tabular}{|l|r|r|r|}
\hline \multirow{2}{*}{ Activity } & \multicolumn{2}{|c|}{ Employees per manager } & \multicolumn{2}{c|}{$\begin{array}{c}\text { Change } \\
2016-2006\end{array}$} \\
\cline { 2 - 4 } & 2016 & 2006 & 0.6 \\
Hospitals & 28.6 & & 27.9 \\
Medical \& other & 26.0 & 31.7 & -5.7 \\
\hline Health services & 27.3 & 29.6 & -2.3 \\
\hline & & & -0.3 \\
\hline
\end{tabular}

Sources: ABS (2007, 2012, 2017a and 2017b).

Table 2: Health and all industry managers by category, Australia, 2006 and 2016

\begin{tabular}{|l|r|r|r|r|}
\hline \multirow{2}{*}{ Industry } & \multicolumn{3}{|c|}{ Category percentage distribution } \\
\cline { 2 - 5 } & $\begin{array}{l}\text { CEO/GM } \\
\text { \& M(nfd) }\end{array}$ & \multicolumn{1}{|c|}{ Specialist } & \multicolumn{1}{c|}{ Service } & \multicolumn{1}{c|}{ All } \\
\hline Health services & 16.3 & 69.2 & 14.5 & 100.0 \\
2016 & 16.6 & 66.6 & 16.8 & 100.0 \\
2006 & & & & \\
\hline Difference & -0.3 & +2.6 & -2.3 & 100.0 \\
$2016-2006$ & 12.0 & 54.6 & 33.4 & 100.0 \\
\hline All Industries & 13.2 & 50.3 & 36.5 & \\
2016 & & & & \\
2006 & -1.2 & +4.3 & -3.1 & \\
\hline Difference & & & & \\
$2016-2006$ & & & & \\
\hline
\end{tabular}

Note: (CEO/GM \& M(nfd)) is the sum of the chief executive officer/general manager category with managers not further defined. Health services is the sum of hospital and medical and other health services.

Sources: ABS (2017a and 2017b); Martins \& Isouard (2012a).

Table 3: Age of managers in health services and all industries, Australia, 2006 and 2016

\begin{tabular}{|l|r|r|r|r|}
\hline Age & \multicolumn{1}{|c|}{ Hospitals } & $\begin{array}{c}\text { Medical \& } \\
\text { other health }\end{array}$ & All health & All industries \\
\hline 2016 & & & & \\
Average age (years) & 48.5 & 45.9 & 47.2 & 44.6 \\
Median age (years) & 49.2 & 46.1 & 47.6 & 44.5 \\
Standard deviation (years) & 10.4 & 11.3 & 10.9 & 12.0 \\
Coefficient of variation & 0.21 & 0.25 & 0.23 & 0.27 \\
\hline & & & & \\
2006 & & & & 43.5 \\
Average age (years) & 47.0 & 44.7 & 46.0 & 43.5 \\
Median age (years) & 47.6 & 45.2 & 46.6 & 11.6 \\
Standard deviation (years) & 9.4 & 10.6 & 10.0 & 0.27 \\
Coefficient of variation & 0.20 & 0.24 & 0.22 & \\
\hline
\end{tabular}

Sources: ABS (2017a and 2017b); Martins \& Isouard (2012b). 
Table 4: Age of managers by category, health services and all industries, Australia, 2006 and 2016

\begin{tabular}{|c|c|c|c|c|c|c|c|c|}
\hline \multirow{2}{*}{$\begin{array}{l}\text { Manager } \\
\text { category }\end{array}$} & \multicolumn{4}{|c|}{$\begin{array}{c}\text { All health } \\
\text { age (years) }\end{array}$} & \multicolumn{4}{|c|}{$\begin{array}{l}\text { All industries } \\
\text { age (years) }\end{array}$} \\
\hline & Average & Median & SD & $\mathrm{CV}$ & Average & Median & SD & $\mathrm{CV}$ \\
\hline 2016 & & & & & & & & \\
\hline $\mathrm{CEO} / \mathrm{GM}$ & 49.8 & 50.2 & 10.7 & 0.21 & 49.1 & 48.9 & 11.2 & 0.23 \\
\hline$M(n f d)$ & 48.0 & 48.3 & 10.8 & 0.23 & 47.3 & 47.1 & 11.9 & 0.25 \\
\hline Specialist & 47.0 & 47.4 & 10.7 & 0.23 & 44.8 & 44.5 & 11.2 & 0.25 \\
\hline Service & 45.7 & 46.0 & 12.1 & 0.27 & 42.9 & 42.4 & 13.2 & 0.31 \\
\hline All 2016 & 47.2 & 47.6 & 10.9 & 0.23 & 44.6 & 44.5 & 12.0 & 0.27 \\
\hline 2006 & & & & & & & & \\
\hline CEO/GM & 47.8 & 48.1 & 9.3 & 0.19 & 47.4 & 47.2 & 10.6 & 0.22 \\
\hline $\mathrm{M}(\mathrm{nfd})$ & 47.4 & 47.4 & 10.3 & 0.22 & 47.2 & 47.1 & 11.7 & 0.25 \\
\hline Specialist & 45.7 & 46.3 & 9.7 & 0.21 & 43.5 & 43.4 & 10.8 & 0.25 \\
\hline Service & 45.4 & 46.6 & 11.0 & 0.24 & 41.9 & 41.9 & 12.5 & 0.30 \\
\hline All 2006 & 46.0 & 46.6 & 10.0 & 0.22 & 43.5 & 43.5 & 11.6 & 0.27 \\
\hline
\end{tabular}

Note: (Health services) are the aggregate of hospitals and medical and other health services. (CEO/GM) are chief executive officers and general managers. $((\mathrm{M}(\mathrm{nfd}))$ are managers not further defined. (SD) is the standard deviation in years. (CV) is the coefficient of variance (proportion).

Sources: ABS (2017b); Martins \& Isouard (2012b).

Table 5: Sex distribution of people employed in health services and all industries, Australia, 2006 and 2016

\begin{tabular}{|l|r|r|r|r|}
\hline \multirow{2}{*}{ Sex } & \multicolumn{3}{|c|}{ Percentage } \\
\cline { 2 - 5 } & Hospitals & $\begin{array}{c}\text { Medical } \\
\text { \& other health }\end{array}$ & All health & All industries \\
\hline 2016 & & & & \\
Females & 78.0 & 73.9 & 76.0 & 47.5 \\
Males & 22.0 & 26.1 & 24.0 & 52.5 \\
\hline 2016 & 30.5 & 26.4 & 28.6 & Standard \\
Relative Difference Index & & & & \\
\hline & & & & \\
2006 & 20.9 & 27.2 & 23.8 & 53.1 \\
Females & & & & \\
Males & 33.3 & 26.9 & 30.3 & Standard \\
\hline 2006 & & & & \\
Relative Difference Index & & & & \\
\hline
\end{tabular}

Note: The relative difference index $=\left[\sum\left|\left\{\left(\mathrm{a}_{\mathrm{i}} / \mathrm{b}_{\mathrm{i}}\right)^{*} 100\right\}-100\right|\right] /(2 * \mathrm{n}) ;\left(\mathrm{a}_{\mathrm{i}}\right)$ is the proportion of employees of sex (i) in given health service; $\left(b_{i}\right)$ is the proportion of employees of sex (i) in all industries; $(n)$ is the number of sex groups.

Sources: ABS (2017b); Martins \& Isouard (2012b). 
Table 6: Sex distribution of managers in health services and all industries, Australia, 2006 and 2016

\begin{tabular}{|l|r|r|r|r|}
\hline \multirow{2}{*}{ Sex } & \multicolumn{4}{|c|}{ Percentage } \\
\cline { 2 - 5 } & Hospitals & $\begin{array}{r}\text { Medical \& } \\
\text { other health }\end{array}$ & $\begin{array}{c}\text { All } \\
\text { health }\end{array}$ & \multicolumn{1}{c|}{$\begin{array}{c}\text { All } \\
\text { industries }\end{array}$} \\
\hline & & & & \\
Females & & & & \\
Males & 63.5 & 60.8 & 62.1 & 38.0 \\
\hline 2016 & 36.5 & 39.2 & 37.9 & 62.0 \\
Female managers to employees \% gap & -14.5 & -13.1 & -13.9 & -9.5 \\
\hline & & & & \\
2006 & & & & 35.2 \\
Females & 61.5 & 58.8 & 60.4 & 64.8 \\
Males & 38.5 & 41.2 & 39.6 & \\
\hline 2006 & & & & -10.9 \\
Female managers to employees \% gap & -17.6 & -14.0 & -15.8 & \\
\hline
\end{tabular}

Note: The female to employee $\%$ gap is the difference between the proportion of female employees and the proportion of managers in the given activity.

Sources: ABS (2017a and 2017b); Table 5; Martins \& Isouard (2012b).

Table 7: Health service managers by category and sex, Australia, 2006 and 2016

\begin{tabular}{|l|r|r|r|r|r|}
\hline \multirow{2}{*}{ Sex } & \multicolumn{5}{|c|}{ Percentage } \\
\cline { 2 - 6 } 2016 & CEO/GM & M(nfd) & Specialist & \multicolumn{1}{|c|}{ Service } & \multicolumn{1}{|c|}{ All } \\
Females & & & & & \\
Males & 53.4 & 62.6 & 64.5 & 58.5 & 62.1 \\
\hline & 46.6 & 37.4 & 35.5 & 41.5 & 37.9 \\
2006 & & & & & \\
Females & 51.6 & 61.0 & 62.6 & 57.4 & 60.4 \\
Males & 48.4 & 39.0 & 37.4 & 42.6 & 39.6 \\
\hline & & & & & \\
Female & & & & & +1.7 \\
$\%$ change 2006-2016 & +1.8 & +1.6 & +1.9 & +1.1 & \\
\hline
\end{tabular}

Note: (CEO/GM) are chief executive officers and general managers. ((M(nfd)) are managers not further defined. Sources: ABS (2017a and 2017b); Martins \& Isouard (2012b). 
Table 8: Health service managers average age by category and sex, Australia, 2006 and 2016

\begin{tabular}{|c|c|c|c|c|c|}
\hline \multirow[b]{2}{*}{ Sex } & \multicolumn{5}{|c|}{ Average years of age } \\
\hline & CEO/GM & $M(n f d)$ & Specialist & Service & All \\
\hline 2016 & & & & & \\
\hline Females & 49.3 & 47.7 & 46.8 & 44.7 & 46.8 \\
\hline Males & 50.3 & 48.3 & 47.6 & 47.0 & 48.0 \\
\hline Persons 2016 & 49.8 & 48.0 & 47.0 & 45.7 & 47.2 \\
\hline 2006 & & & & & \\
\hline Females & 47.6 & 46.7 & 45.2 & 45.1 & 45.5 \\
\hline Males & 48.1 & 48.3 & 46.5 & 45.8 & 46.7 \\
\hline Persons 20016 & 47.8 & 47.4 & 45.7 & 45.6 & 46.0 \\
\hline $\begin{array}{l}\text { 2006-2016 Persons' age } \\
\text { years difference }\end{array}$ & +2.0 & +0.6 & +1.3 & +0.3 & +1.2 \\
\hline
\end{tabular}

Note: (CEO/GM) are chief executive officers and general managers. ((M(nfd)) are managers not further defined.

Sources: ABS (2017b); Martins \& Isouard (2012b).

Table 9: Field of study of managers in health services and all industries, Australia, 2016

\begin{tabular}{|l|r|r|r|r|}
\hline & \multicolumn{4}{|c|}{ Percentage of total } \\
\cline { 2 - 5 } Field of study & Hospitals & $\begin{array}{c}\text { Medical \& } \\
\text { other health }\end{array}$ & $\begin{array}{c}\text { All } \\
\text { health }\end{array}$ & \multicolumn{1}{c|}{$\begin{array}{c}\text { All } \\
\text { industries }\end{array}$} \\
\hline & & & & \\
Management \& commerce & 30.0 & 28.5 & 29.3 & 26.8 \\
Health & 31.8 & 25.0 & 28.4 & 3.2 \\
Social \& related fields & 9.4 & 12.0 & 10.7 & 10.5 \\
Natural \& physical sciences & 3.0 & 7.3 & 5.2 & 2.7 \\
Engineering \& related fields & 4.1 & 3.4 & 3.7 & 11.5 \\
Information technology & 2.9 & 2.4 & 2.7 & 3.5 \\
Education & 1.9 & 2.8 & 2.4 & 4.1 \\
Food, hospit. \& personal care & 2.2 & 1.2 & 1.7 & 3.3 \\
Architecture \& building & 1.1 & 0.7 & 0.9 & 5.7 \\
Other & 13.5 & 16.7 & 15.1 & 28.7 \\
\hline & & & & 100.0 \\
All fields of study & 100.0 & 100.0 & 100.0 & 100.0 \\
\hline
\end{tabular}

Note: Other includes a very small proportion of managers in agriculture and environment field of study, inadequately defined and not stated and those without tertiary/diploma/certificate completed education. Source: ABS (2017b). 
Table 10: Field of study of managers in health services and all industries, by sex, Australia, 2016

\begin{tabular}{|l|r|r|r|r|}
\hline \multirow{2}{*}{ Field of study } & \multicolumn{4}{|c|}{ Sex percentage } \\
\cline { 2 - 5 } & \multicolumn{2}{|c|}{ All health } & \multicolumn{2}{c|}{ All industries } \\
\cline { 2 - 5 } Management \& commerce & \multicolumn{1}{|c|}{ Females } & \multicolumn{1}{c|}{ Females } & \multicolumn{1}{c|}{ Males } \\
Health & 59.9 & 40.1 & 43.6 & 56.4 \\
Social \& related fields & 70.9 & 29.1 & 64.7 & 35.3 \\
Natural \& physical sciences & 71.8 & 28.2 & 56.9 & 43.1 \\
Engineering \& related fields & 55.6 & 44.4 & 38.9 & 61.1 \\
Information technology & 12.0 & 88.0 & 5.9 & 94.1 \\
Education & 21.1 & 78.9 & 17.6 & 82.4 \\
Food, hospit. \& personal care & 77.5 & 22.5 & 64.5 & 35.5 \\
Architecture \& building & 60.2 & 39.8 & 51.9 & 48.1 \\
Other & 17.4 & 82.6 & 5.9 & 94.1 \\
\hline & 65.9 & 34.1 & 39.7 & 60.2 \\
All fields of study & & & & \\
\end{tabular}

Note: Other includes a very small proportion of managers in agriculture and environment field of study, inadequately defined and not stated and those without tertiary/diploma/certificate completed education. Source: ABS (2017b). 
Table 11: Level of education of health and all industries managers, Australia, 2006 and 2016

\begin{tabular}{|c|c|c|c|c|}
\hline \multirow[b]{2}{*}{ Level of education } & \multicolumn{4}{|c|}{ Percentage of all levels } \\
\hline & Hospitals & $\begin{array}{c}\text { Medical \& } \\
\text { other health }\end{array}$ & $\begin{array}{c}\text { All } \\
\text { health }\end{array}$ & $\begin{array}{c}\text { All } \\
\text { industries }\end{array}$ \\
\hline 2016 & & & & \\
\hline Postgraduate & 34.5 & 24.3 & 29.4 & 14.2 \\
\hline Bachelor & 29.9 & 33.7 & 31.8 & 25.4 \\
\hline & 64.4 & 58.0 & 61.2 & 39.6 \\
\hline Diploma/certificate & 22.5 & 26.7 & 24.6 & 33.2 \\
\hline Other \& not stated & 13.1 & 15.3 & 14.2 & 27.1 \\
\hline All & 100.0 & 100.0 & 100.0 & 100.0 \\
\hline $\begin{array}{l}\text { Relative } \\
\text { difference index }\end{array}$ & 30.6 & 20.9 & 25.7 & Standard \\
\hline 2006 & & & & \\
\hline Postgraduate & 29.9 & 20.7 & 25.8 & 9.6 \\
\hline Bachelor & 29.1 & 31.2 & 30.0 & 19.9 \\
\hline & 59.0 & 51.9 & 55.8 & 29.5 \\
\hline Diploma/certificate & 22.1 & 26.8 & 24.1 & 31.5 \\
\hline Other \& not stated & 19.0 & 21.3 & 20.0 & 39.0 \\
\hline All & 100.0 & 100.0 & 100.0 & 100.0 \\
\hline $\begin{array}{l}\text { Relative } \\
\text { difference index }\end{array}$ & 42.4 & 29.1 & 36.5 & Standard \\
\hline
\end{tabular}

Note: The relative difference index $=\left[\sum\left|\left\{\left(a_{\mathrm{i}} / \mathrm{b}_{\mathrm{i}}\right) * 100\right\}-100\right|\right] /(2 * \mathrm{n}) ;\left(\mathrm{a}_{\mathrm{i}}\right)$ is the proportion of employees of level of education (i) in given health service; $\left(b_{i}\right)$ is the proportion of employees of level of education (i) in all industries; (n) is the number of level of education groups.

Source: ABS (2017b). 
Table 12: Level of education of hospital and medical and other health service managers by category, Australia, 2016

\begin{tabular}{|c|c|c|c|c|c|}
\hline \multirow[b]{2}{*}{ Level of education } & \multicolumn{5}{|c|}{ Percentage of all level of education } \\
\hline & $\mathrm{CEO} / \mathrm{GM}$ & $\mathrm{M}(\mathrm{nfd})$ & Specialist & Service & All \\
\hline \multicolumn{6}{|c|}{ Hospitals } \\
\hline Postgraduate & 44.2 & 36.8 & 37.4 & 8.1 & 34.5 \\
\hline Bachelor & 31.3 & 25.8 & 32.7 & 12.5 & 29.9 \\
\hline & 75.5 & 62.6 & 70.1 & 20.6 & 64.4 \\
\hline Diploma/certificate & 15.1 & 19.1 & 19.5 & 47.2 & 22.5 \\
\hline Other \& not stated & 9.5 & 18.3 & 10.3 & 32.2 & 13.1 \\
\hline All & 100.0 & 100.0 & 100.0 & 100.0 & 100.0 \\
\hline \multicolumn{6}{|c|}{ Medical \& other health services } \\
\hline Postgraduate & 33.2 & 23.9 & 26.3 & 8.8 & 24.3 \\
\hline Bachelor & 34.3 & 30.0 & 36.8 & 22.1 & 33.7 \\
\hline & 67.5 & 53.9 & 63.1 & 30.9 & 58.0 \\
\hline Diploma/certificate & 20.0 & 28.6 & 24.2 & 41.8 & 26.7 \\
\hline Other \& not stated & 12.4 & 17.5 & 12.8 & 27.4 & 15.3 \\
\hline All & 100.0 & 100.0 & 100.0 & 100.0 & 100.0 \\
\hline
\end{tabular}

Note: CEO/GM are chief executive officers and general managers. M(nfd) are managers not further defined. Percentages may not add due to rounding.

Source: ABS (2017b). 
Table 13: Level of education of health services managers, by sex and category, Australia, 2016

\begin{tabular}{|c|c|c|c|c|c|}
\hline \multirow[b]{2}{*}{ Level of education } & \multicolumn{5}{|c|}{ Female and male percentage in level by category } \\
\hline & $\mathrm{CEO} / \mathrm{GM}$ & $M(n f d)$ & Specialist & Service & All \\
\hline \multicolumn{6}{|c|}{ Females } \\
\hline Postgraduate & 34.5 & 29.6 & 32.4 & 7.7 & 29.2 \\
\hline Bachelor & 32.4 & 25.4 & 34.4 & 19.1 & 31.8 \\
\hline & 66.9 & 55.0 & 66.8 & 26.8 & 61.0 \\
\hline Diploma/Certificate & 19.9 & 24.7 & 21.8 & 37.2 & 23.8 \\
\hline Other \& not stated & 13.2 & 20.3 & 11.4 & 36.1 & 15.3 \\
\hline \multicolumn{6}{|c|}{ Males } \\
\hline Postgraduate & 41.8 & 26.7 & 32.0 & 9.6 & 29.8 \\
\hline \multirow[t]{2}{*}{ Bachelor } & 33.8 & 33.9 & 35.0 & 16.3 & 31.8 \\
\hline & 75.6 & 60.6 & 67.0 & 25.9 & 61.6 \\
\hline Diploma/Certificate & 15.6 & 26.2 & 21.5 & 54.0 & 25.9 \\
\hline Other \& not stated & 8.8 & 13.2 & 11.5 & 20.2 & 12.5 \\
\hline
\end{tabular}

Note: (CEO/GM) are chief executive officers and general managers. ((M(nfd)) are managers not further defined. Percentages may not add up due to rounding.

Source: ABS (2017b).

Table 14: Average weekly gross income of managers in health services and all industries, Australia, 2006 and 2016

\begin{tabular}{|l|r|r|r|r|}
\hline & \multicolumn{4}{|c|}{ Weekly income (\$) } \\
\cline { 2 - 5 } Weekly income & Hospitals & $\begin{array}{c}\text { Medical \& } \\
\text { other health }\end{array}$ & $\begin{array}{c}\text { All } \\
\text { health }\end{array}$ & $\begin{array}{c}\text { All } \\
\text { industries }\end{array}$ \\
\hline Average & & & & \\
Median & 2,188 & 1,991 & 2,089 & 1,894 \\
Standard deviation & 1,985 & 1,721 & 1,865 & 1,589 \\
Coefficient of variation & 1,010 & 1,132 & 1,077 & 1,185 \\
\hline & 0.46 & 0.57 & 0.52 & 0.63 \\
2006 & & & & 1,341 \\
Average & 1,548 & 1,436 & 1,499 & 882 \\
Median & 1,411 & 1,261 & 1,362 & 0.66 \\
Standard deviation & 769 & 827 & 799 & \\
Coefficient of variation & 0.50 & 0.58 & 0.53 & +41.2 \\
\hline
\end{tabular}

Sources: ABS (2017b); Martins \& Isouard (2012c). 
Table 15: Average weekly gross income of managers in health services and all industries, by category, Australia, 2016

\begin{tabular}{|l|r|r|r|r|}
\hline \multirow{2}{*}{ Category } & \multicolumn{4}{|c|}{ Percentage above (+) or below (-) average weekly income } \\
\cline { 2 - 5 } & \multicolumn{1}{|c|}{ Hospitals } & $\begin{array}{c}\text { Medical \& } \\
\text { other health }\end{array}$ & $\begin{array}{c}\text { All } \\
\text { health }\end{array}$ & $\begin{array}{c}\text { All } \\
\text { industries }\end{array}$ \\
\hline & & & & +28.9 \\
CEO/GM & +27.0 & +32.0 & -3.7 & +38.8 \\
M(nf) & +1.9 & -5.2 & +1.9 & +2.9 \\
Specialist & +1.9 & +1.9 & -34.1 & -34.2 \\
Service & -35.6 & -32.0 & & \\
\hline All managers & & & 2,089 & 1,894 \\
average weekly income (\$) & 2,188 & 1,991 & & \\
\hline
\end{tabular}

Source: ABS (2017b).

Table 16: Average hours worked the week before the census by managers in health services and all industries, Australia, 2006 and 2016

\begin{tabular}{|l|r|r|r|r|}
\hline & \multicolumn{4}{|c|}{ Average hours worked } \\
\cline { 2 - 5 } Weekly work hours & Hospitals & $\begin{array}{c}\text { Medical \& } \\
\text { other health }\end{array}$ & $\begin{array}{c}\text { All } \\
\text { health }\end{array}$ & $\begin{array}{c}\text { All } \\
\text { industries }\end{array}$ \\
\hline & & & & \\
Average & 43.2 & 42.0 & 42.6 & 46.0 \\
Median & 40.4 & 40.3 & 40.4 & 40.8 \\
Standard deviation & 16.6 & 17.5 & 17.1 & 17.8 \\
Coefficient of variation & 0.38 & 0.42 & 0.40 & 0.41 \\
\hline & & & & \\
2006 & 41.9 & 41.9 & 41.9 & 46.9 \\
Average & 39.7 & 39.8 & 39.7 & 19.6 \\
Median & 17.2 & 18.5 & 17.8 & 0.42 \\
Standard deviation & 0.41 & 0.44 & 0.42 & \\
Coefficient of variation & & & & -0.9 \\
\hline & & & +0.7 & \\
2016-2006 & +1.3 & +0.1 & +0.7 & \\
\% change of average & & & & \\
\hline
\end{tabular}

The figures exclude managers who did not state the number of hours worked: $0.5 \%$ in health services, and $0.9 \%$ in all industries in 2016; and 1.1\% in health services and $1.7 \%$ in all industries in 2006.

Sources: ABS (2017b); Martins \& Isouard (2012d). 
Table 17: Average hours worked the week before the census by managers in health services and all industries, by category, Australia, 2016

\begin{tabular}{|l|r|r|r|r|}
\hline \multirow{2}{*}{ Category } & \multicolumn{4}{|c|}{ Average hours worked per week } \\
\cline { 2 - 5 } & \multicolumn{1}{|c|}{ Hospitals } & $\begin{array}{c}\text { Medical \& } \\
\text { other health }\end{array}$ & $\begin{array}{c}\text { All } \\
\text { health }\end{array}$ & \multicolumn{1}{c|}{$\begin{array}{c}\text { All } \\
\text { industries }\end{array}$} \\
\hline & & & & \\
CEO/GM & 46.6 & 48.0 & 47.4 & 51.3 \\
M(nf) & 44.3 & 40.7 & 42.0 & 45.8 \\
Specialist & 43.4 & 41.4 & 42.5 & 46.5 \\
Service & 38.8 & 39.4 & 39.1 & 43.8 \\
\hline & & & & \\
All & 43.2 & 42.0 & 42.6 & 46.0 \\
\hline
\end{tabular}

Note: The figures exclude managers who did not state the number of hours worked: $0.5 \%$ in hospitals, medical and other health services, and $0.9 \%$ in all industries.

Source: ABS (2017b).

Table 18: Average hours worked the week before the census by managers in hospitals and medical and other health services by sex, Australia, 2016

\begin{tabular}{|l|r|r|r|r|}
\hline \multirow{2}{*}{ Weekly work hours } & \multicolumn{4}{|c|}{ Hours worked per week } \\
\cline { 2 - 5 } & \multicolumn{2}{|c|}{ Hospitals } & \multicolumn{1}{c|}{ Medical \& other services } \\
\cline { 2 - 5 } Average & & \multicolumn{1}{c|}{ Memales } & Males \\
Median & 41.8 & 45.7 & 39.2 & 46.4 \\
Standard deviation & 40.3 & 40.6 & 39.9 & 40.8 \\
Coefficient of variation & 16.8 & 15.9 & 17.0 & 17.4 \\
\hline
\end{tabular}

Note: The figures exclude managers who did not state the number of hours worked: $0.5 \%$ in hospitals, medical and other health services, and $0.9 \%$ in all industries.

Source: ABS (2017b).

Table 19: Managers working less than 35 hours per week before the census in health services and all industries by sex, Australia, 2006 and 2016

\begin{tabular}{|c|c|c|c|c|}
\hline \multirow[b]{2}{*}{ Sex } & \multicolumn{4}{|c|}{ Percentage of managers working less than 35 hours per week } \\
\hline & Hospital & $\begin{array}{c}\text { Medical } \\
\& \text { other health }\end{array}$ & $\begin{array}{c}\text { All } \\
\text { health }\end{array}$ & $\begin{array}{c}\text { All } \\
\text { industries }\end{array}$ \\
\hline 2016 & & & & \\
\hline Females & 23.3 & 29.5 & 26.3 & 25.4 \\
\hline Males & 9.2 & 12.7 & 11.0 & 10.5 \\
\hline 2016 all & 18.2 & 22.9 & 20.5 & 15.3 \\
\hline 2006 & & & & \\
\hline Females & 21.3 & 28.5 & 24.4 & 24.8 \\
\hline Males & 9.0 & 12.0 & 10.3 & 9.7 \\
\hline 2006 All & 16.5 & 21.7 & 18.9 & 15.0 \\
\hline
\end{tabular}

The figures exclude managers who did not state the number of hours worked: $0.5 \%$ in health services, and $0.9 \%$ in all industries in 2016; and 1.1\% in health services and $1.7 \%$ in all industries in 2006.

Sources: ABS (2017b); Martins \& Isouard (2012d). 
Table 20: Average hours worked the week before the census by full-time managers in health services and all industries, by sex, Australia, 2016

\begin{tabular}{|c|c|c|c|c|}
\hline \multirow[b]{2}{*}{ Sex } & \multicolumn{4}{|c|}{ Average hours worked per week } \\
\hline & Hospitals & $\begin{array}{c}\text { Medical \& } \\
\text { other health }\end{array}$ & $\begin{array}{c}\text { All } \\
\text { health }\end{array}$ & $\begin{array}{c}\text { All } \\
\text { industries }\end{array}$ \\
\hline Female & 48.0 & 47.1 & 47.6 & 48.8 \\
\hline Male & 48.5 & 50.5 & 49.5 & 53.2 \\
\hline All & 48.2 & 48.6 & 48.4 & 51.7 \\
\hline
\end{tabular}

Note: Full-time managers are defined as those working 35 hours or more per week. The figures exclude managers who did not state the number of hours worked: $0.5 \%$ in health services, and $0.9 \%$ in all industries. Source: ABS (2017b).

Table 21: Managers who worked more than 48 and less than 16 hours the week before the census in health services and all industries, by sex, Australia, 2016

\begin{tabular}{|c|c|c|c|c|}
\hline \multirow[b]{2}{*}{ Sex } & Hospitals & $\begin{array}{l}\text { Medical \& } \\
\text { other health }\end{array}$ & $\begin{array}{c}\text { All } \\
\text { health }\end{array}$ & $\begin{array}{c}\text { All } \\
\text { industries }\end{array}$ \\
\hline & \multicolumn{4}{|c|}{ Percentage of managers working 49 hours or more per week } \\
\hline Female & 20.1 & 16.6 & 18.4 & 21.4 \\
\hline Male & 25.1 & 29.5 & 27.4 & 37.9 \\
\hline \multirow[t]{2}{*}{ All } & 21.9 & 21.6 & 21.8 & 29.8 \\
\hline & \multicolumn{4}{|c|}{ Percentage of managers working 15 hours or less per week } \\
\hline Female & 12.8 & 17.4 & 15.1 & 15.3 \\
\hline Male & 6.0 & 8.5 & 7.3 & 6.9 \\
\hline All & 10.3 & 13.9 & 12.1 & 9.5 \\
\hline
\end{tabular}

The figures exclude managers who did not state the number of hours worked: $0.5 \%$ in health services, and $0.9 \%$ in all industries.

Source: ABS (2017b). 
Table 22: Marital status of health service managers and all industries, Australia, 2006 and 2016

\begin{tabular}{|l|r|r|r|r|}
\hline & \multicolumn{4}{|c|}{ Percentage } \\
\cline { 2 - 5 } Marital status & Hospitals & $\begin{array}{c}\text { Medical } \\
\text { \& other health }\end{array}$ & $\begin{array}{c}\text { All } \\
\text { health }\end{array}$ & $\begin{array}{c}\text { All } \\
\text { industries }\end{array}$ \\
\hline & & & & \\
Ne16 & 17.6 & 20.6 & 19.1 & 24.0 \\
Married & 66.5 & 65.0 & 65.9 & 63.9 \\
Divorced/separated & 14.6 & 13.4 & 13.9 & 11.2 \\
Widowed & 1.3 & 1.0 & 1.1 & 0.9 \\
\hline & & & & 100.0 \\
All 2016 & 100.0 & 100.0 & 100.0 & \\
\hline & & & & 21.9 \\
2006 & 16.9 & 19.3 & 17.9 & 11.3 \\
Never married & 66.0 & 66.2 & 66.1 & 0.9 \\
Married & 15.4 & 13.4 & 14.5 & 100.0 \\
Divorced/separated & 1.6 & 1.2 & 1.4 & \\
Widowed & 100.0 & 100.0 & 100.0 & \\
\hline & & & & \\
All 2006 & & & & \\
\hline
\end{tabular}

Note: Figures may not add up due to rounding. (Married) includes those in a partnership.

Sources: ABS (2017b); Martins \& Isouard (2012d). 
Table 23: Country of birth of health service managers and all industries, Australia, 2006 and 2016

\begin{tabular}{|c|c|c|c|c|}
\hline \multirow[b]{2}{*}{ Country of birth } & \multicolumn{4}{|c|}{ Percentage } \\
\hline & Hospitals & $\begin{array}{l}\text { Medical } \\
\& \text { other } \\
\text { health }\end{array}$ & $\begin{array}{c}\text { All } \\
\text { health }\end{array}$ & $\begin{array}{c}\text { All } \\
\text { industries }\end{array}$ \\
\hline 2016 & & & & \\
\hline Australia & 72.1 & 67.3 & 69.7 & 68.7 \\
\hline New Zealand \& Oceania & 3.8 & 3.5 & 3.7 & 3.8 \\
\hline United Kingdom \& Ireland & 10.1 & 9.3 & 9.7 & 7.7 \\
\hline Other Europe & 2.9 & 2.9 & 2.9 & 3.8 \\
\hline Other & 11.1 & 17.0 & 14.0 & 16.0 \\
\hline All 2016 & 100.0 & 100.0 & 100.0 & 100.0 \\
\hline 2006 & & & & \\
\hline Australia & 75.6 & 72.5 & 74.3 & 73.2 \\
\hline New Zealand \& Oceania & 2.8 & 3.2 & 3.0 & 3.5 \\
\hline United Kingdom \& Ireland & 11.1 & 10.1 & 10.7 & 8.4 \\
\hline Other Europe & 7.5 & 9.7 & 8.4 & 10.9 \\
\hline Other & 3.0 & 4.5 & 3.6 & 4.1 \\
\hline All 2006 & 100.0 & 100.0 & 100.0 & 100.0 \\
\hline
\end{tabular}

Note: Health service managers who did not state their country of birth constituted $1.5 \%$ of the total in 2006 and $1.0 \%$ in 2016. Figures may not add up due to rounding.

Sources: ABS (2017b); Martins \& Isouard (2012d).

Table 24: Indigenous status of health service managers and all industries, Australia, 2006 and 2016

\begin{tabular}{|l|r|r|r|r|}
\hline \multirow{2}{*}{ Sex } & \multicolumn{4}{|c|}{ Indigenous percentage } \\
\cline { 2 - 5 } & Hospitals & $\begin{array}{c}\text { Medical } \\
\text { \& other } \\
\text { health }\end{array}$ & $\begin{array}{c}\text { All } \\
\text { health }\end{array}$ & $\begin{array}{c}\text { All } \\
\text { industries }\end{array}$ \\
\hline 2016 & & & & \\
Females & 1.5 & 2.3 & 1.9 & 1.2 \\
Males & 1.0 & 2.0 & 1.5 & 0.8 \\
\hline & & & & \\
All 2016 & 1.3 & 2.2 & 1.7 & 0.9 \\
\hline & & & & 0.8 \\
2006 & 1.0 & 1.5 & 1.3 & 0.5 \\
Females & 0.8 & 1.5 & 1.1 & 0.6 \\
Males & & & & \\
\hline & 1.0 & 1.5 & 1.2 & 0.1 \\
All 2006 & & & & \\
\hline
\end{tabular}

Note: Managers who did not state their indigenous/non-indigenous status constituted $0.6 \%$ in all industries and $0.5 \%$ in health services in 2006 and $0.4 \%$ in both cases in 2016 .

Sources: ABS (2017b); Martins \& Isouard (2012d). 